\title{
GLYCOGEN LOADING: ADVANTAGES BUT POSSIBLE DISADVANTAGES
}

\author{
IVAN M. SHARMAN, BSc, PhD, CChem, FRSC, FRSH
}

Dunn Nutrition Unit, Cambridge

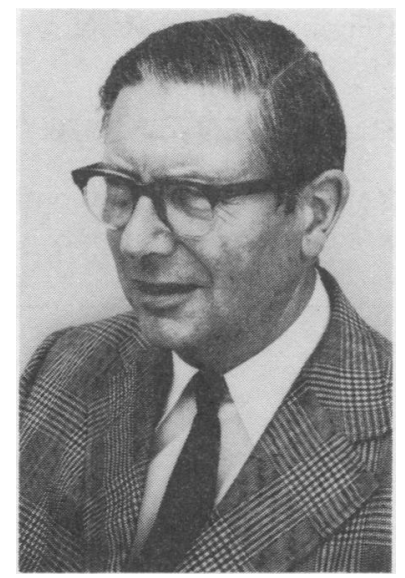

\section{INTRODUCTION}

In today's competitive atmosphere in athletics it is not surprising that sportsmen have turned their attention to diet in the hope that some increment in performance might be attained by the ingestion of some special food - or perhaps by eating a larger amount of some standard food. It is not expected that a large increase in performance would thereby result but even if a very small increment were attained it might make all the difference between winning and losing a race.
\end{abstract}

ABSTRACT

Carbohydrate loading enables an athlete to build up stores of muscle glycogen. Such raised levels increase work times and are therefore of real benefit to long-distance runners. It is unclear how frequently the regimen can be repeated with the same advantageous results. There are possible disadvantages in the regimen, and even dangers in older subjects.

The subject of nutrition and athletic performance is by no means a new one. Records exist to show that in those far off days of the Grecian Olympic Games the athlete was concerned with what he ate. In the centuries that followed, experience, tradition and the fads and fancies of coaches and trainers have all contributed to the components of the sportsman's diet.

As nutrition developed during the present century to a science it is perhaps surprising, even disappointing, that in general nothing has been firmly proved about any particular item of food being especially suitable for athletes. Nevertheless the science of nutrition has opened the door to the idea of "supercharging" the body with those nutrients believed to be of particular importance for the athlete. One of the more imaginative attempts in this direction was the suggestion that the queen bee substance, or "Royal Jelly", should be included in the athlete's diet.

\section{VITAMINS}

On somewhat firmer ground is the proposal that extra vitamins may aid performance. Thus there are arguments for believing that additional vitamin $E$ may be required by the body when it is in a state of stress such as participating in a strenuous race. For instance, it is known that a deficiency of this vitamin in various experimental animals causes the muscles to become dystrophic, and it could be argued that when muscles are under stress an increased demand for the vitamin, which is not provided by a normal diet, is made. If this were so then the provision of extra vitamin $E$ might well be expected to increase performance. At Loughborough trials have been carried out in which we gave swimmers large doses of the vitamin, $400 \mathrm{mg}$ daily and compared their performance with that of similar subjects given a placebo; in a double-blind trial we found no further increment in performance when the vitamin was administered (Sharman, et al, 1976). Under the conditions of our trial therefore, the vitamin did not act as an ergogenic aid.

\section{ATP/PHOSPHATE CYCLE}

We come on much firmer ground when we consider the energy requirements of the sportsman, since diet must be sufficient to meet the high demands of the athlete. Baldwin (1963) has answered the question "How do muscles obtain their energy?" by the statement "Living organisms, like machines, conform to the law of the conservation of energy and must pay for all their activities in the currency of metabolism". Thus the building-up of glycogen stores in muscles is the most likely method whereby nutrition can aid the athlete to better his performance.

Evidence from muscle biopsy by Swedish investigators has demonstrated conclusively that carbohydrates play 
an essential role in the building-up of glycogen in the muscles. By the use of this technique it has been possible to make the following deductions:

1 Muscle glycogen drops steadily during moderately heavy exercise.

2 This fall is confined to the exercised muscles determined by the use of a cycle ergometer modified so that only one leg was exercised. Specimens could thereby be collected from both exercised and nonexercised muscles of the same subject.

3 The time for which muscles can work is directly related to the glycogen stored in them. $V$

4 Changes in diet can alter the glycogen content of muscle. This is perhaps the most important deduction in the present context of considering how nutrition can aid the sportsman.

Energy for muscle contraction comes ultimately from dietary sources, though the immediate source is adenosine triphosphate (ATP). When the latter substance splits into adenosine diphosphate (ADP) and phosphoric acid it provides the actual power for muscle contractions. However, as muscles contain only small amounts of ATP the compound must continuously be resynthesised. This is achieved by the recombination of its breakdown products, the necessary energy being provided by another energy-yielding reaction in the cell, the splitting of creatine phosphate. This additional "phosphagen" also is present only in small quantities and therefore needs to be remade constantly. There are two ultimate sources of energy for the resynthesis of the "phosphagens": the combustion of food, and glycolysis, the breakdown of glycogen with the formation of lactic acid. The latter process is reversible so that an input of energy from food combustion will cause a resynthesis of glycogen. Altogether there are five reactions that have to be considered. Three of them, "phosphagen" splitting, food combustion, and glycolysis, provide energy whilst the other two - "phosphagen" resynthesis and the reconstitution of glycogen - absorb energy.

Examples of typical muscle glycogen contents are given in Table I. Alongside the values corresponding average work times are also shown.

\section{TABLE I}

Muscle glycogen as influenced by diet

$\begin{array}{lcc} & \begin{array}{c}\text { Glycogen } \\ \text { content } \\ \mathbf{g} / \text { 100g muscle }\end{array} & \begin{array}{c}\text { Average } \\ \text { work time }\end{array} \\ \begin{array}{lcc}\text { min } \\ \text { After a normal mixed diet }\end{array} & 1.75 & 126 \\ \begin{array}{l}\text { After protein-fat diet } \\ \text { After almost wholly } \\ \text { carbohydrate diet }\end{array} & 0.63 & 59 \\ & 3.3 & 189\end{array}$

It can be seen that by increasing the glycogen content of the muscle by giving a high carbohydrate diet the average work time is increased significantly.

\section{TABLE II}

\section{High protein-fat diet}

Breakfast : $\quad \begin{aligned} & \text { Lean bacon } \\ & \text { Eggs } \\ & 1 \text { slice starch reduced bread, diabetic marmalade } \\ & \text { Tea/coffee, synthetic sweetener, milk }\end{aligned}$
Lunch : $\quad \begin{aligned} & \text { Lamb chop/steak } \\ & \text { Brussels sprouts, runner beans } \\ & \text { Yoghurt/cheese } \\ & \text { Tea/coffee/milk }\end{aligned}$
Supper : $\quad \begin{aligned} & \text { Grilled cod } \\ & \text { Cauliflower/tomata } \\ & \text { Cheese, one slice starch reduced bread } \\ & \text { Tea/coffee/milk }\end{aligned}$

Typical high protein-fat and high carbohydrate diets are shown in Tables II and III.

\section{TABLE III}

\section{High carbohydrate diet}

$\begin{array}{ll}\text { Breakfast : } & \begin{array}{l}\text { Porridge/cornflakes, milk, sugar } \\ \text { Toast, marmalade } \\ \text { Tea/coffee, milk, sugar }\end{array} \\ \text { Lunch : } \quad \begin{array}{l}\text { Sausages, chipped potatoes, baked beans in } \\ \text { tomato sauce } \\ \text { Gateaux } \\ \text { Tea/coffee, milk, sugar }\end{array} \\ \text { Supper : } \quad \begin{array}{l}\text { Soup } \\ \text { Roast beef, Yorkshire pudding, potatoes, peas } \\ \text { Canned peaches, custard } \\ \text { Tea/coffee, milk, sugar }\end{array}\end{array}$

\section{GLYCOGEN LOADING}

From the results of the Swedish investigations, Asstrand (1967) made the following recommendation for athletes. They should first exhaust their existing stores of muscle glycogen by performing moderately heavy work and then, after a short period on a high protein-fat diet they should feed almost exclusively on carbohydrates. This is believed to be a most effective way of building up a large store of muscle glycogen. It allows the athlete to perform exhausting work for a longer time than he would otherwise be able to do.

\section{Limitations and possible disadvantages}

While there is no doubt that carbohydrate loading can 
be beneficial to a long distance or marathon runner, a number of limitations and possible disadvantages must be borne in mind. It is not known how frequently the regimen can be repeated with the same desired effect nor whether the procedure is entirely innocuous. Another criticism of the technique is that by building up glycogen stores, weight is increased, because glycogen in both liver and muscles retains extra water. However, as will be shown later, there is a loss in body weight in the preliminary stage on a high protein-fat diet, which partly offsets this increase in weight. As a first step towards answering the question of whether the procedure is entirely innocuous, a trial with healthy athletes was carried out with colleagues at the Alfred Chester Beatty Body Dynamics Laboratory at Cranbrook, and at St. Mary's College of Education at Twickenham (Heeley, et al, 1975).

A high protein-fat diet, similar to that detailed above, was given to six healthy young men for four days. Blood specimens were collected at the start and termination of the investigation. Urine was collected for the 24 hour period immediately preceding, and during the last 24 hours of, the special diet. Body weights were measured before and after the dietary procedure.

Table IV shows the ages and weights of the subjects.

\section{TABLE IV}

Ages and weights of subjects

\begin{tabular}{lllll} 
Subject & $\begin{array}{l}\text { Age } \\
\text { (yr) }\end{array}$ & \multicolumn{2}{c}{ Woight (kg) } & \\
Initial & Find & Loss \\
C & 21.5 & 73.8 & 72.5 & 1.3 \\
D & 20.8 & 62.2 & 60.1 & 2.1 \\
H & 24.4 & 70.7 & 69.0 & 1.7 \\
M & 21.0 & 66.0 & 64.7 & 1.3 \\
O & 21.3 & 96.6 & 96.0 & 0.6 \\
P & 19.8 & 70.0 & 68.3 & 1.7 \\
Average & 21.5 & 73.2 & 71.8 & 1.4 \\
& & & &
\end{tabular}

It will be seen that in every subject there was a loss of body weight, with a mean loss of $1.4 \mathrm{~kg}$. As has already been pointed out this will partly offset the criticism that an increase in body weight will result from a high carbohydrate diet.

Blood specimens were subsequently analysed, and results showed interesting differences between specimens taken before and at the end of the study. Thus there were significant average rises in urea $(4.65$ to 8.13 $\mathrm{mmol} / \mathrm{l})$, cholesterol (4.66 to $5.52 \mathrm{mmol} / \mathrm{l})$, total phosphorus (2.87 to $3.16 \mathrm{mmol} / \mathrm{l})$, phosphatides (2230 to
$2440 \mathrm{mg} / \mathrm{l}$ ) and in osmolality (282 to $293 \mathrm{mosmol} / \mathrm{l}$ ). There were also significant falls in triiodothyronine levels (83 to $31 \%)$ and in glucose $(4.90$ to $4.53 \mathrm{mmol} / \mathrm{l})$.

In urine, significant changes were also observed. Average rises were found in urea from 22.5 to 38.7 $\mathrm{g} / 24$ hours, and in cyclic AMP from 15.7 to 31.5 $\mu \mathrm{mol} / 24$ hours. There was also a significant rise in chromium from 6.01 to $11.68 \mu \mathrm{g} / 24$ hours. A significant average fall in uric acid from 2.89 to $0.62 \mathrm{mmol} / 24$ hours was also noted.

Various other indices measured both in blood and urine did not show any significant differences. Thus the average fasting level of insulin in the blood fell from 9.9 to $7.1 \mu \mathrm{U} / \mathrm{ml}$ but this difference was not significant. However, when the values for an exceptionally obese subject were removed, the mean values were 10.2 and $5.7 \mu \mathrm{U} / \mathrm{ml}$ and this difference was significant.

The implications of the differences found in this investigation are being examined further to see whether they suggest any evidence against the practice of carbohydrate loading.

\section{Dangers in older distance runners}

The possible dangers that may accrue from the use of carbohydrate loading by older runners have been voiced by Mirkin and Spring (1973). These authors cited the case of a 40-year-old man who had started running ten years previously because of a high cholesterol level in his blood serum. During the intervening years he had acquired some proficiency in distance running and had run a marathon in less than $2 \mathrm{~h} 50 \mathrm{~m}$. At the time of the. observations he was training on 18.6 to $24.8 \mathrm{~km} / \mathrm{wk}$ with one long run and two others of moderate length. His body weight was $67.8 \mathrm{~kg}$ and he had a serum cholesterol level of $240 \mathrm{mg}$.

Four weeks before he was due to run another marathon he ran $16.2 \mathrm{~km}$ in $59 \mathrm{~m}$ without undue effort. From days seven to five before the marathon he changed to a diet of cheese, meat and turkey. On days four to two before the event he added as much bread as he could consume. It is recorded that at one sitting he ate almost two loaves. On day three he felt a dull pain on the left side of his chest; on the following day the pain became more severe and constant. An electrocardiogram showed flattening and inversion of the T-wave and depression of the S-T segment. He changed immediately to one small meal a day and decided not to participate in the marathon. The pain subsided within five days.

The observations reported in this case raise serious questions not only about the wisdom of applying carbohydrate loading in older distance runners, but also the desirability of those susceptible to infarction eating large meals at night. 
A possible criticism of carbohydrate loading was the fact that it increased body weight, which in its turn was detrimental to the athlete. It was shown that the increase was partly offset by the reduction in weight that resulted from the earlier period on a high proteinfat diet.

\section{Need for drinks whilst running a marathon}

A questionnaire was issued to competitors in the AAA Marathon Championship in 1975, which indicates that some increase in body water may not be without its advantages, (Newton, 1980).

Of the 149 competitors who finished the race, 109 (73\%) returned forms. They were divided firstly into groups depending on whether they finished comfortably, in slight distress, in acute distress, or retired. The subgroups were again divided into those who were on the Saltin (glycogen loading) diet and those who were not. The numbers in each group and subgroup are shown in Table V.

\section{TABLE V}

Numbers completing race and on Saltin diet

\begin{tabular}{|c|c|c|c|}
\hline & Total & $\begin{array}{l}\text { On Saltin } \\
\text { diet }\end{array}$ & $\begin{array}{l}\text { Not on } \\
\text { Saltin diet }\end{array}$ \\
\hline Finished comfortably & 54 & 26 & 28 \\
\hline Finished in slight distress & 47 & 22 & 25 \\
\hline Finished in acute distress & 8 & 3 & 5 \\
\hline Retired & 14 & 5 & 9 \\
\hline Total: & 123 & 56 & 67 \\
\hline
\end{tabular}

\section{REFERENCES}

Åstrand, P.O., 1967 “Diet and athletic performance". Federation Proceedings 26: 1772-1777.

Baldwin, E., 1963 “Dynamic aspects of biochemistry". 4th Edition. Cambridge University Press, London: 57.

Heeley, D. M., Sharman, I. M. and Cooper, D. F., 1975 “Variations in the composition of blood and urine following the ingestion of a high protein diet". Proceedings of the Nutrition Society 34: 69A.

Mirkin, G. and Spring, S., 1973 "Carbohydrate loading: a dangerous practice". Journal of the American Medical Association 223: (13): 1511-1512.

Newton, F., 1980 Private communication.

Sharman, I. M., Down, M. G. and Norgan, N. G., 1976 “The effects of vitamin E on physiological function and athletic performance of trained swimmers". Journal of Sports Medicine and Physical Fitness 16: 215-225.

\section{DISCUSSION}

Dr. Press: Dr. Sharman implied that although there was evidence that a low-carbohydrate diet was necessary after the depletion of glycogen stores before the change to a high-carbohydrate diet, this might no longer be the case. Is there any evidence that this period of a high-protein, high-fat diet is unnecessary?

Dr. Sharman: Nowadays, it is accepted that the same beneficial results can be obtained without the protein diet. If this is the case, the question of adverse effects from a high-protein diet does not arise. 